\title{
Is Cyclone JAL Stimulated Chlorophyll-A Enhancement Increased Over the Bay of Bengal?
}

\author{
Muni Krishna $\mathrm{K}^{1 *}$ and Manjunatha $\mathrm{B}^{2}$ \\ ${ }^{1}$ Department of Meteorology and Oceanography, Andhra University, India \\ ${ }^{2}$ Department of Marine Geology, Mangalore University, India
}

Submission: September 09, 2019; Published: October 18, 2019

Corresponding author: K Muni Krishna, Department of Meteorology and Oceanography, Andhra University, Visakhapatnam, India

\begin{abstract}
Tropical cyclone JAL developed in the south Bay of Bengal and worn south coastal Andhra Pradesh on November 7, 2010. The main objective of this study was to investigate the ocean's response before and after the passage of cyclone in the southern Bay by utilizing the multi-satellite approach. For this study, I used Sea Surface Temperature (SST), Chlorophyll-a (Chl-a), and Sea Surface Height (SSH) data production from different remote sensing satellites. JAL induced large scale of upwelling within large cooling of sea surface $\left(\sim 1.2^{\circ} \mathrm{C}\right)$, enhancement of $\mathrm{Chl}-\mathrm{a} \sim 0.4$ $\mathrm{mg} / \mathrm{m}^{3}$ in the open ocean and $2-3 \mathrm{mg} / \mathrm{m}^{3}$ along the coast, and decrease of SSH $(\sim 15 \mathrm{~cm})$ in the southeast Bay of Bengal after its passage. After the JAL, the upwelling area expanded rapidly on the shelf break. Chl-a images also revealed high values $\left(\sim 3.3 \mathrm{mg} / \mathrm{m}^{3}\right)$ appeared in the shelf region, where the high Chl-a patterns matched the upwelling in terms of location and time. Large offshore surface cooling was also observed mainly to the right of the cyclone track. From the above observations it is evident that cyclonic storm JAL significantly increased upwelling in the southern Bay of Bengal.
\end{abstract}

Keywords: Cyclone; Sea surface height; Chorophll-a

\section{Introduction}

Cyclones pose a great havoc to coastal cities and its gale winds changes the upper ocean properties in the tropics. Previous studies reveal that strong cooling is observed along the cyclone track [1-3]. It also plays an important role in enhancing phytoplankton bloom and primary productivity in oligotrophic oceanic waters, especially in cyclone-dominated seas. The Bay of Bengal is the most vulnerable region to hazard of intense tropical cyclones during pre-monsoon (April-May) and post monsoon (October - December) seasons [4]. In recent years the bay experience more than 5 cyclones during the post monsoon season compared with the Arabian Sea. Tropical cyclones depend on the ocean for their energy supply. Observations have shown that the state of the ocean has a great influence on the intensities, structures, and even paths of tropical cyclones [5-9]. Upper ocean is greatly influenced by the cyclone gale winds. The wind stress and pressure drop associated with tropical cyclone generate turbulent mixing in the ocean, generate ocean currents, and alters the ocean's thermal structure. Strong wind momentum helps to bring the subsurface water from a depth of $60 \mathrm{~m}$, because of that the surface water shows strong cooling $\left(1-7^{\circ} \mathrm{C}\right)$ also the very deep mixed layer during post cyclone stage [10-
13]. This cooling is mainly due to the vertical turbulent mixing induced by the strong momentum flux into ocean currents and accompanied entrainment of cooler thermocline water into the upper mixed layer. The magnitude of the surface cooling plays a vital role on reduction of the energy supply to cyclone for further intensification [13]. The main purpose of the study is to examine the physical and biological changes in the upper layers of the Bay water at different stages of Jal cyclone.

\section{Data and Methodology}

\section{Cyclone Track}

India Meteorological department provided the cyclone data which includes maximum sustained surface wind speed and location of the cyclone center every 6 hours interval during 1 - 7 November 2010 (www.imd.go.in).

\section{Satellite data}

Daily Sea surface temperature merged product (AVHRR+AMSR-E) at a spatial resolution of $25 \mathrm{~km}$ from Remote Sensing System (www.remss.com) for the study of physical response. Biological changes like chlorophyll-a concentration 
observed from MODIS satellite and seas surface heights were obtained from TOPEX/Poseidon satellite.

\section{Results and Discussion}

On November 1, 2010, a depression was formed in the south Bay of Bengal and it continued moving west slowly. Late on November 3, it took a form a tropical cyclone that prevailed on November 4 and 5. Early on November 6, it further strengthened into category 1 storm, which was named "JAL". On November 7 weaken into a cyclonic storm and further weaken into a Deep Depression and made landfall near Chennai. Before the arrival of JAL cyclone, SSTs were $29.2-30.2^{\circ} \mathrm{C}$ in the whole study region of $7-16^{\circ} \mathrm{N}, 78-90^{\circ} \mathrm{E}$. Soon after JAL's passage, a large region of cooling occurred, as the first available AVHRR-AMSR SST image of November 9 has indicated (Figure 1). Generally, SSTs of 27.8 $28.4^{\circ} \mathrm{C}$ were detected over the area of $10-13^{\circ} \mathrm{N}, 83-86^{\circ} \mathrm{E}$. The size of the patch was about $300 \mathrm{~km} 2$. Note that the SST dropped as much as $1.4^{\circ} \mathrm{C}$ on average. The location of the cold patch agreed with most of the reported results of cyclone induced cooling [14], which was to the right of the track, but in this case left side cooling area was also observed. However, the drop of SST was the most significant cyclone cooling cases reported so far.
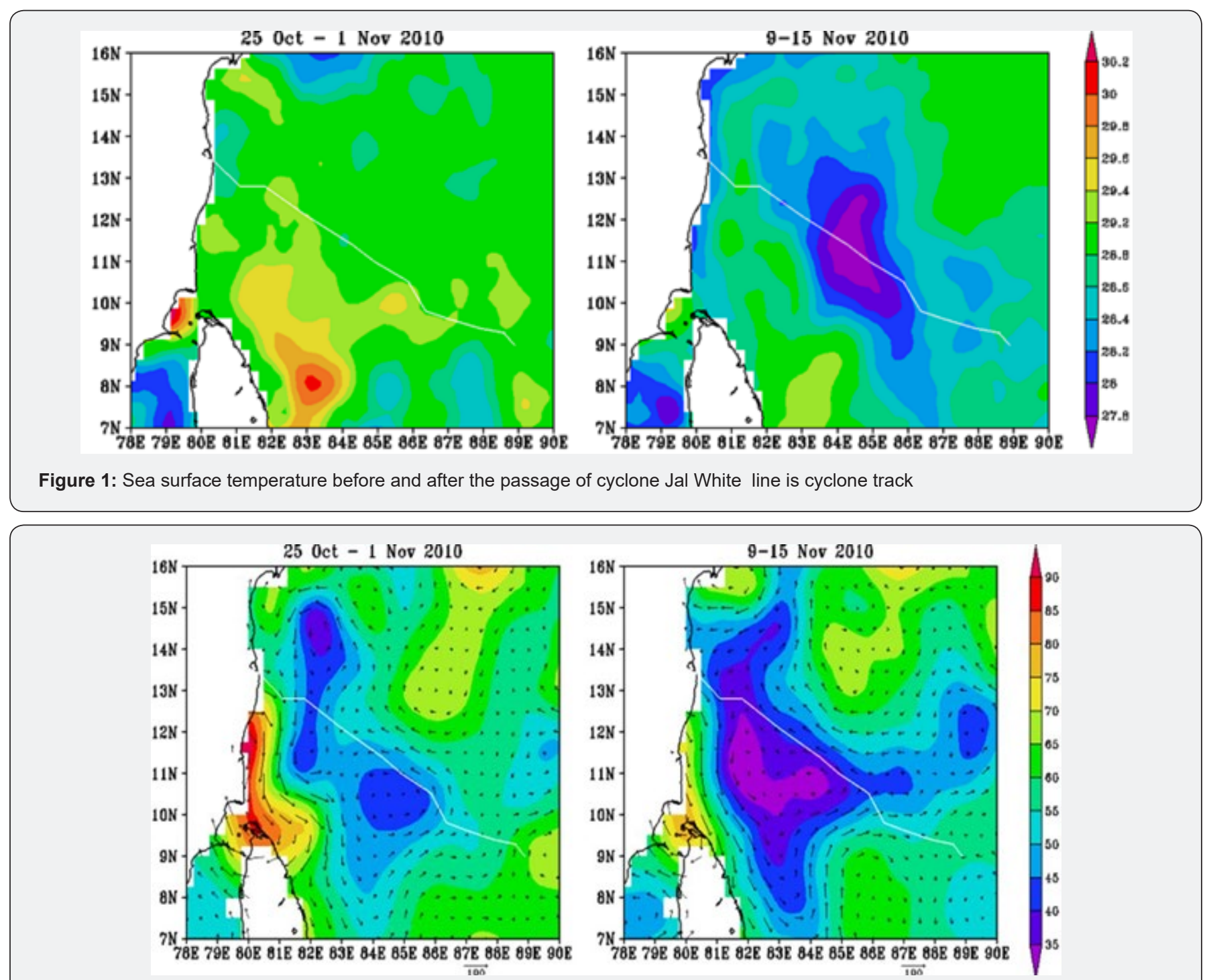

Figure 2: Sea surface height and geostrophic currents (arrows) before and after the cyclone White line represents cyclone track.

In the area of tremendous cooling, SSH data showed a preexisting anticyclonic eddy (Figure2), which together with another located in the southern basin (north of $10^{\circ} \mathrm{N}$ ), formed a basin scale anticyclonic circulation in November driven by the northeast monsoon prevailing in this season. Changes in SSH before and after JAL demonstrated that a maximum cooling of $\sim 1.2^{\circ} \mathrm{C}$ was located in the area of minimum $\mathrm{SSH}$, and the magnitude of cooling decreased with increasing SSH (Figure2). Thus, the strong winds of JAL (60-70 knots) had drastically intensified cyclonic circulation. The highest drop of SSH was up to $15 \mathrm{~cm}$. Therefore, the occurrence of a cold Chl-a patch after JAL's passage in such an area was conceivable. Cyclone induced 
strong upwelling together with entrainment mixing over the water, which had originally had an upward doming of cold water due to eddy pumping, resulted in Chl-a enhancement both from upward entrainment of the phytoplankton to the surface from the deep Chl-a maximum and from new nutrient injection from the deeper water into the upper water.
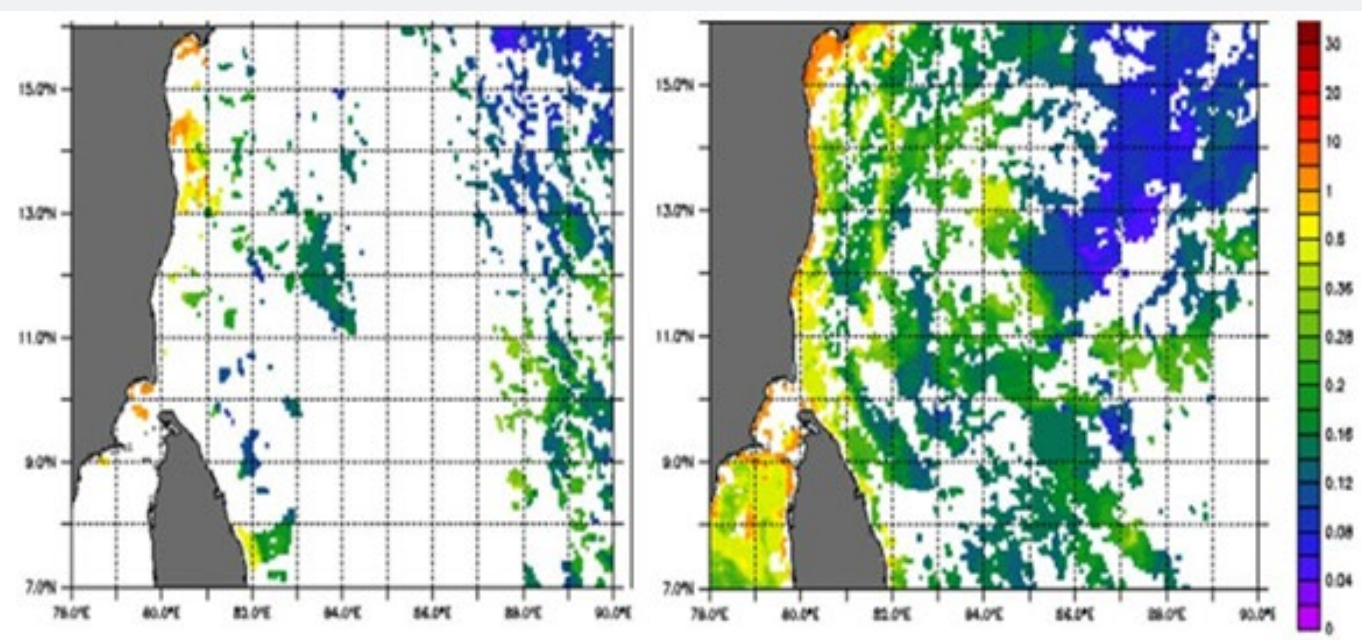

Figure 3: Satellite derived chlorophyll-a concentration before and after the JAL cyclone.

Figure 3 depicts satellite derived chl-a concentration images on the last week of October (before JAL) and the second week of November (After JAL) respectively. These images clearly show biological responses of the cyclone-induced ocean. Chl-a concentrations were low at $0.01-0.12 \mathrm{mg} / \mathrm{m} 3$ for the whole south-central Bay of Bengal before the JAL cyclone. Two days after the passage of JAL cyclone both open ocean and coastal waters (right side of track, where the cyclone crossed the land) got enriched with nutrient due to the vertical mixing and entrainment process. Strong chl-a concentration with a magnitude of $\sim 0.5-0.65 \mathrm{mg} / \mathrm{m} 3$ observed off Chennai. It coincides with the center of the cyclone eye and the cooling area (Figure 1). The phenomena are clearly observed in the Chl-a images and coincide with the cooling area ( $\sim 300 \mathrm{~km})$. The enhancement of chl-a is more along the coast compared with the open ocean.

\section{Conclusion}

In the Bay of Bengal, Jal cyclone induced physical and biological changes were explored used remote sensing observations. An extreme cooling area was observed in the south-central Bay of Bengal after the passage of JAL. This cooling area of approximately $300 \mathrm{Sq} \mathrm{km}$ occupied both left and right sides of track. The cooling area, lowering of sea surface height and enhanced Chl-a area were well matched in the open ocean. Coupled models (ROMS and NEMO) require for further study of the subsurface dynamics and other nutrients.

\section{Acknowledgment}

I am grateful to Indian Meteorological Department, Remote Sensing Systems, GSFC and AVISO for provide cyclone and satellite data products.

\section{References}

1. Price J F, T Sanford, G Forristall (1996) Forced stage response to a moving hurricane. Journal of Physical Oceanography 24 (2): 233-260.

2. Jacob S D, L K Shay, A J Mariano,P G Black (2000) The 3d mixed layer response to hurricane Gilbert. Journal of Physical Oceanography 30: 1407-1429.

3. K Muni Krishna (2016) Observational study of upper ocean cooling due to Phet Super Cyclone in the Arabian Sea. Advance inSpace Research 57(10): 2115-2120.

4. K Muni Krishna (2009) Intensifying Tropical Cyclones over the North Indian Ocean during Summer Monsoon - Global Warming. Global and Planetary Change 65(1-2): 12-16.

5. EL Fisher (1958) Hurricane and the sea surface temperature field . Journal of Meteorology 15: 328-333.

6. CF Tisdale and PF Clapp (1963) Origin and paths of hurricanes and tropical storms related to certain physical parameters at the air-sea interface. Journal of Applied Meteorology 2: 358-367.

7. S Brand (1971) The effects on tropical cyclones of cooler surface waters due to upwelling and mixing produced by a prior tropical cyclone. Journal of Applied Meteorology 10: 865-874.

8. PG Black (1977) Interaction of Hurricane Ginger with the North Atlantic. Part I: Ocean response and restoration time and space scale as revealed by sea surface temperature changes. National Hurricane and Experimental Meteorology Laboratory.

9. SW Chang and RA Anthes (1979) Mutual response of Tropical Cyclone and the Ocean. Journal of Physical Oceanography 129: 128-135.

10. PG Black (1983) Ocean temperature changes induced by tropical cyclones. The Pennsylvania State University, pp. 278.

11. M A Benderand I Ginis (2000) Real-case simulations of hurricaneocean interaction using a high resolution coupled model: effects on hurricane intensity. Monthly Weather Review 128: 917-946. 
12. B Jena, MVRao, BK Sahu (2006) TRMM derived sea surface temperature in the wake of a cyclonic storm over the central Bay of Bengal. International Journal of Remote Sensing 27(14): 3065-3072.

13. ND Walker, R R Leben, S Balasubramanian (2005) Hurricaneforced upwelling and chlorophyll a enhancement within cold-core cyclones in the Gulf of Mexico.Geophysical Research Letters 32(18): 610.
14.SM Babin, J A Carton, T D Dickey and J D Wiggert (2004) Satellite evidence of hurricane-induced phytoplankton blooms in an oceanic desert. Journal of Geophysical Research 109: C3.

\section{Your next submission with Juniper Publishers} will reach you the below assets

- Quality Editorial service

- Swift Peer Review

- Reprints availability

- E-prints Service

- Manuscript Podcast for convenient understanding

- Global attainment for your research

- Manuscript accessibility in different formats

( Pdf, E-pub, Full Text, Audio)

- Unceasing customer service

Track the below URL for one-step submission https://juniperpublishers.com/online-submission.php 